https://doi.org/10.17816/MAJ191S141-43

\title{
POLYMORPHISM OF INTERLEUKIN 10 IN PATIENTS WITH AN IRRITABLE BOWEL SYNDROME DEPENDING ON PSYCHOPATHOLOGICAL DISORDERS
}

\author{
D.S. Stashkevich, A.L. Burmistrova \\ Microbiology, Immunology and General Biology Department of Biological Faculty, \\ Chelyabinsk State University, Chelyabinsk, Russia

\section{ПОЛИМОРФИЗМ ИНТЕРЛЕЙКИНА 10 У БОЛЬНЫХ С СИНДРОМОМ РАЗДРАЖЕННОГО КИШЕЧНИКА В ЗАВИСИМОСТИ ОТ ПСИХОПАТОЛОГИЧЕСКИХ РАССТРОЙСТВ}

\author{
Д.С. Сташкевич, А.Л. Бурмистрова \\ ФГБОУ ВО «Челябинский государственный университет», Челябинск
}

Irritable bowel syndrome, which is a common functional intestinal disorder, can be attributed to psychosomatic pathology, since it contains all three characteristic features of this group of diseases. The study assessed discrimination in the distribution of alleles and genotypes -1082G/A, 819C/T, -592C/A IL-10 in groups of patients with IBS with various psychopathological disorders. The peculiarities of the distribution of alleles and genotypes formed by the polymorphic site -592C/A IL-10 were identified. For groups of patients with "IBS with anxiety disorders" and "IBS with depressive syndrome", the frequencies of the rare allele and its heterozygous genotype -592C/A were increased. According to the criterion of the odds ratio, prognostic significance was an increase in the carrier frequency only in the group of patients "IBS with anxiety disorders" $(\mathrm{OR}=3.9,95 \% \mathrm{CI} 1.3-12.5)$. It has been established that the polymorphism $-592 \mathrm{C} / \mathrm{A}$ of the IL-10 gene was associated with the variant "IBS with anxiety disorders".

Keywords: IBS; interleukin 10; genetic polymorphism.

Синдром раздраженного кишечника, являющийся распространенным функциональным кишечным расстройством, можно отнести к психосоматической патологии, поскольку он содержит все три характерных признака этой группы заболеваний. В исследовании проведена оценка дискриминации распределения аллелей и генотипов $-1082 \mathrm{G} / \mathrm{A},-819 \mathrm{C} / \mathrm{T},-592 \mathrm{C} / \mathrm{A}$ IL-10 в группах больных CPK с различными психопатологическими расстройствами. Выявлены особенности распределения аллелей и генотипов, образованных полиморфным сайтом -592C/A IL-10. Для групп больныХ «СРК с тревожными расстройствами» и «СРК с депрессивным синдромом» повышены частоты редкого аллеля и его гетерозиготного генотипа -592С/А. Согласно критерию отношения шансов прогностическое значение имеет повышение частоты носительства только в группе больных с вариантом «СРК с тревожными расстройствами» $(\mathrm{OR}=3,9,95 \%$ CI 1,3-12,5). Установлено, что полиморфизм -592C/A гена IL-10 ассоциирован с вариантом «СРК с тревожными расстройствами».

Ключевые слова: СРК; интерлейкин 10; генетический полиморфизм.

Introduction. Irritable Bowel Syndrome (IBS) is a common functional intestinal disorder, the pathophysiology of which is being intensively studied and characterized by the following risk factors: reconstruction of the microbial community of the digestive tract, infectious gastroenteritis in the anamnesis, visceral hypersensitivity, disruption of the "microbiota - immune system - brain axis", chronic stress and genetic factors. [1]. Most modern researchers recognize IBS as a psychosocial disorder, as one of the typical examples of the functional psychosomatic illness of the digestive tract [2]. According to modern concepts, inflammatory reactions are the most important pathogenetic mechanism of chronic non-infectious diseases, including mental and neurodegenerative diseases [3].

According to different data, one of the key regulators of the inflammatory response is interleukin 10 (IL-10). The production of IL-10 can be affected by genetic polymorphisms within the coding and promoter region of its gene, which is containing a large number of polymorphic sites, among which the most studied three points in the promoter region: $-1082 \mathrm{G} / \mathrm{A},-819 \mathrm{C} / \mathrm{T},-592 \mathrm{C} / \mathrm{A}$. Therefore, a genetic predisposition for the high or low production of IL-10 may affect disease susceptibility and clinical outcome. For example, a genetic predisposition for low IL-10 production is associated with the development of IBS [4].

Aim. To assess the discrimination of the distribution of alleles and genotypes $-1082 \mathrm{G} / \mathrm{A}$, $-819 \mathrm{C} / \mathrm{T},-592 \mathrm{C} / \mathrm{A}$ IL-10 in groups of patients with IBS with various psychopathological disorders.

Material and methods. The study belongs to the retrospective type. Groups of IBS with various psychopathological conditions are allocated according to T.A. Klimusheva [5]: IBS without neuropsychiatric disorders (Group 1) - 20 people, IBS 
Frequencies of alleles and genotypes of IL-10 in various psychopathological disorders

\begin{tabular}{|c|c|c|c|c|c|c|c|c|c|}
\hline \multirow{2}{*}{ Alleles/genotypes } & \multicolumn{2}{|c|}{ Group 1} & \multicolumn{2}{|c|}{ Group 2} & \multicolumn{2}{|c|}{ Group 3} & \multicolumn{2}{|c|}{ Group 4} & \multirow{2}{*}{ veracity } \\
\hline & $n$ & $\%$ & $n$ & $\%$ & $n$ & $\%$ & $n$ & $\%$ & \\
\hline$-592 * \mathrm{~A}$ & 5 & 12.5 & 14 & 36.8 & 12 & 31.6 & 13 & 29.5 & \multirow{2}{*}{$\begin{array}{c}\chi^{2}=6.6 ; p=0.087 \\
\text { df }=3\end{array}$} \\
\hline$-592 * \mathrm{C}$ & 35 & 87.5 & 24 & 63.2 & 26 & 68.4 & 31 & 70.5 & \\
\hline$-592 \mathrm{AA}$ & 0 & 0 & 0 & 0 & 0 & 0 & 3 & 13.6 & \multirow{3}{*}{$\begin{array}{c}\chi^{2}=20.4 ; p=0.01 \\
\mathrm{df}=6\end{array}$} \\
\hline$-592 \mathrm{CA}$ & 5 & 25 & 14 & 73.7 & 12 & 63.2 & 7 & 31.8 & \\
\hline$-592 \mathrm{CC}$ & 15 & 75 & 5 & 26.3 & 7 & 36.8 & 12 & 54.8 & \\
\hline
\end{tabular}

with anxiety disorders (Group 2) - 19 people, IBS with depressive syndrome (Group 3) - 19 people, IBS with hypochondriac syndrome (Group 4) 22 person. The SNPs of IL-10 gene were determined by allele-specific PCR (Liteh, Moscow) with subsequent UV detection of the results in a $3 \%$ agarose gel. Statistical processing was carried out using standard immunogenetic methods: $\chi^{2}$ criteria, odds ratio (OR) with the calculation of the $95 \%$ confidence interval $(\mathrm{CI})$.

In all cases, the differences were considered statistically significant when $p \leq 0.05$, insignificant with $p>0.10$; for intermediate values of $p$ $(0.05 \leq p \leq 0.10)$ the tendency towards differences was discussed.

Results and discussion. Earlier, we established the features of the frequency distribution of IL-10 SNPs in patients with IBS of Caucasian origin. The polymorphic site -592C/A IL-10 is of greater importance in the implementation of susceptibility to IBS. The frequency of rare allele $-592 * A$ was increased in IBS group [6]. At the next stage, an analysis was made of the frequency of occurrence of alleles and genotypes formed by polymorphic loci $-1082 \mathrm{G} / \mathrm{A},-819 \mathrm{C} / \mathrm{T},-592 \mathrm{C} / \mathrm{A}$ in various variants of psychopathological disorders in patients with IBS. Significant differences between groups were obtained for SNP -592C/A.

Results were shown in Tabl. 1.

As can be seen from the table, an increase in the frequency of the rare allele $\left(-592^{*} \mathrm{~A}\right)$ is characteristic for groups of patients with "IBS with anxiety disorders" and "IBS with depressive syndrome" (trend). These changes are realized by increasing the frequency of the heterozygous genotype -592C/A. According to the odds ratio criterion, the carriage of a heterozygous genotype increases the likelihood of the development of "IBS with anxiety disorders" by 3.9 times $(\mathrm{OR}=3.9$, 95\% CI 1.3-12.5).

However, the increase in the carrier status of the heterozygous genotype -592C/A was statistically insignificant for the group of "IBS with depressive syndrome" $(\mathrm{OR}=2.1,95 \%$ CI $0.7-6.1)$. Only in the group of "IBS with hypochondriac syndrome" carriers of the homozygous genotype were identified for the allele with the substitution $-592 \mathrm{~A} / \mathrm{A}$, but this increase was not statistically significant.

Thus, the polymorphism of the $-592 \mathrm{C} / \mathrm{A}$ gene IL-10 is associated with some variants of psychopathological disorders in patients with IBS, namely with the option "IBS with anxiety disorders."

\section{References}

1. Shukla R, Ghoshal U, Ranjan P, C Ghoshal U. Expression of Toll-like Receptors, Pro-, and Antiinflammatory Cytokines in Relation to Gut Microbiota in Irritable Bowel Syndrome: The Evidence for Its Microorganic Basis. Neurogastroenterol Motil. 2018;24(4). https://doi.org/10.5056/jnm18130.

2. Esaulov VI. Experience of application of different psychotherapeutic techniques in the treatment of patients with irritable bowel syndrome. Sovremennye problemy nauki i obrazovanija. 2016;6. http://scienceeducation.ru/ru/article/view?id=25468.

3. Glass ChK, Saijo K, Winner B, et al. Mechanisms underlying inflammation in neurodegeneration. Sovremennye problemy nauki i obrazovanija. Cell. 2010;140:918-934.

4. Qin SY, Jiang HX, Lu DH, Zhou Y. Association of interleukin-10 polymorphisms with risk of irritable bowel syndrome: A meta-analysis. World J Gastroenterol. 2013;28:9472-9480.

5. Klimusheva TA. Irritable bowel syndrome by the eyes of psychiatrist. Russian Journal of Gastroenterology, Hepatology, Coloproctology. 2008;4:82-86.

6. Stashkevich DS, Burmistrova AL, Ivanova EL, et al. Polymorphism association of the il-10 gene promotional area with predisposition to the infrared intestinal syndrome in Russian Chelyabinsk region. Vestnik Ural'skoj medicinskoj akademicheskoj nauki. 2012;4(41):245-246. 